\title{
Studi Komparasi Metode Pembelajaran dalam Meningkatkan Literasi Keuangan di Masa Pandemi Covid-19
}

\author{
Yogi Dwi Satrio*1, Sri Handayani², M. Hasyim Ibnu Abbas ${ }^{3}$, Januar Kustiandi ${ }^{4}$ \\ Program Studi Pendidikan Ekonomi \\ Universitas Negeri Malang \\ Malang, Indonesia
}

e-mail: yogi.dwi.fe@um.ac.id*1, sri.handayani.fe@um.ac.id²

muhammad.hasyim.fe@um.ac.id ${ }^{3}$, januar.kustiandi.fe@um.ac.id ${ }^{4}$

Riwayat Artikel Tanggal diajukan: 8 Juni 2020

Tanggal diterima : 18 Juni 2020

Tanggal dipublikasikan: 29 Juni 2020
Pengutipan:

Satrio, Y.D.

Handayani, S., Abbas, M.H.I. \& Kustiandi, J. (2020). Studi Komparasi Metode Pembelajaran Dalam Meningkatkan

Literasi

Keuangan di

Masa Pandemi

Covid-19. Jurnal

Pendidikan

Ekonomi

Undiksha, 12 (1),

29-35

\begin{abstract}
Abstrak
Serangan pandemic COVID-19 cukup memukul perekonomian dan social masyarakat. Kegiatan ekonomi runtuh, psikologi dalam berekonomi masyarakat terguncang karena banyaknya Batasan-batasan beraktivitas. Logika ekonomi dalam berkonsumsi dan produksi tidak bisa dinalar lagi. Literasi keuangan merupakan hal yang tidak bisa dipisahkan dalam kehidupan seseorang, karena merupakan skill penting yang dapat dimanfaatkan untuk membuat keputusan-keputusan ekonomi. Banyak program sebelum pandemic ini telah dilakukan untuk meningkatkan literasi keuangan masyarakat, baik dikalangan masyarakat umum maupun dalam kependidikan, hanya saja evaluasi belum dilakukan. Dengan menggunakan metode komparasi, Peneliti mengkaji tentang kondisi literasi keuangan pelajar (mahasiswa) pada Pendidikan tinggi berdasarkan metode pembelajaran yang diterapkan di masa pandemi. Metode analisis yang digunakan dalam penelitian ini adalah independent $t$ test dengan berdasarkan metode pengajaran yang dilaksanakan, jumlah responden terbagi menjadi 2, 46 mahasiswa pada kelas online learning dan 46 mahasiswa pada kelas game based learning. Hasil penelitian menunjukkan bahwa tidak tidak ada perbedaan rata-rata skor literasi keuangan dengan kedua variabel pengamatan.
\end{abstract}

Kata kunci: literasi keuangan; game based learning; pembelajaran daring

\section{Abstract}

The COVID-19 pandemic attack the economy and society. Economic activity collapses, the economic activity of the community experiences a setback due to many socio-economic restrictions. The logic of economic action from consumption and production works out of reason. Literasi keuangan cannot be separated in life. Literasi keuangan is an important skill that can be used to make economic decisions. Many pre-pandemic programs have been carried out to increase Financial Literacy. In the field of education students have been taught to be more sensitive in applied economics, only an evaluation tool for the effectiveness of methods that have not been accommodated. Researchers examine the condition of literasi keuangan at university level students. Based on the learning methods applied during the pandemic, using the score collection method. The analytical method used in this study was an independent t-test based on the teaching method implemented, respondents were divided into 2 group, 46 students in online learning classes and 46 students in game based learning classes. The results showed that the learning method at home learning was not significant enough to develop individual literasi keuangan.

Keywords : financial literacy; game based learning; online learning 


\section{PENDAHULUAN}

Serangan virus COVID-19 cukup menggemparkan dan merubah kehidupan manusia. Menghambat populasi, aktivitas pendidikan, terhentinya aktivitas ekonomi, dan menciptakan malapetaka besar bagi kalangan menengah kebawah. Pandemi telah menggantikan kebiasaan, seluruh ritme kehidupan seakan terbalik 180 derajat. Semua orang meremehkan, bahkan sampai sekarang mungkin masih banyak orang yang tidak mengira bahwa pandemic virus COVID-19 yang muncul pertama dari Wuhan, China ini bisa sebesar sekarang (Zhang \& Ma, 2020; Li et al., 2020; Ramaci, Barattucci, \& Ledda, 2020). Ada kontradiksi antara tugas garda terdepan (dokter, perawat dan pendidik) yang berusaha menghentikan persebaran virus dengan masyarakat yang abai pada protokol kesehatan dan mematik penularan eksponensial. Kondisi tersebut tidak bisa disalahkan, di Indonesia sendiri, perekonomian Indonesia sudah mulai ditopang oleh komponen rumah tangga (Nurfitriyani, 2019). Cukup wajar jika masyarakat lebih mengutamakan untuk tidak kelaparan daripada memikirkan terpapar virus.

Kebiasaan-kebiasaan produksi dan konsumsi terpaksa berhenti karena pandemic. Pada kondisi seperti ini, orang harus pandai-pandai dalam mengelola keuangan. Literasi keuangan merupakan hal yang tidak bisa dipisahkan dalam kehidupan seseorang, karena merupakan skill penting yang dapat dimanfaatkan untuk membuat keputusan-keputusan ekonomi. Literasi keuangan yang rendah menyebabkan keputusan ekonomi yang salah dan berpotensi pada kegagalan ekonomi (Satrio, 2012; Murniatiningsih, 2017). Banyak program sebelum pandemic telah dilakukan untuk mening-katkan literasi keuangan masyarakat, baik dikalangan masyarakat umum maupun dalam kependidikan. Seperti yang sudah dilakukan pemerintah pada SNLKI (2017) yaitu dengan menentukan 3 program strategis antara lain: 1) cakap keuangan, 2) sikap dan perilaku keuangan bijak, 3) akses keuangan.

Di tingkat Pendidikan tinggi sudah cukup banyak penelitian dan program peningkatan literasi keuangan pelajar.
Hanya saja, banyaknya program peningkatan literasi keuangan tidak memiliki alat evaluasi yang tepat. Peneliti menganggap evaluasi merupakan salah satu cara yang sangat penting untuk mengukur dampak pembangunan literasi keuangan berkelanjutan seperti yang dilakukan oleh Prosper Canada \& FCAC (Kerr, 2016).

Rasionalitas dalam berkonsumsi selalu berkaitan dengan Pendidikan. Pendidikan tidak hanya berkaitan dengan penilaian kognitif saja, tapi juga mengasah sisi afektif dan psikomotorik pelajar. Peneliti berpandangan bahwa materi-materi dalam keilmuan ekonomi cukup membekali pelajar dalam keterampilan dasar literasi keuangan yang kedepannya sangat bermanfaat bagi peningkatan kesejah-teraan (Akmal \& Saputra, 2016; Satrio, 2012). Serangan pandemic COVID-19 telah merubah semua kebiasaan. Pendidikan. Dari pembelajaran yang tatap muka dengan segala strateginya, kini tidak bisa berjalan dengan optimal. Proses belajar mengajar harus dilaksanakan dalam jaringan.

Peran Pendidikan harus tetap berjalan dalam meningkatkan literasi keuangan pelajar sebagai calon generasi berikutnya. Keterbatasan akses pembe-lajaran sedikitdemi sedikit dengan budaya belajar online. Mayoritas pengajar di Indonesia banyak menggunakan metode belajar ceramah, diskusi dan penugasan dalam jaringan. (Chang, Liang, Chou, \& Lin, 2017; Jagušt, Botički, \& So, 2018; Wardoyo, Dwi Satrio, \& Ma'ruf, 2020) Pelajar dituntut mampu menyelesaikan tugas-tugas, dan komponenkomponen penilian terstruktur yang sudah disiapkan pengajar. Sejalan dengan waktu, banyak pelajar yang mengeluhkan bahwa pembelajaran ekonomi dengan metode tersebut membosankan. Kondisi tersebut mendapat respon dari pengajar dengan menyelipkan game dalam pembelajaran online. Tapi apakah pembelajaran tersebut cukup memberikan dampak dan peranan terhadap literasi keuangan pelajar?.

Pada paper ini dibahas dua variable pengamatan yang dijalankan pada masa pandemic. Metode pengajaran dengan menggunakan learning management system berbasis penugasan terstruktur yang diwakilkan dengan variable online learning, 
dan variable pembelajaran dengan metode pembelajaran berbasis game.

Pembelajaran online adalah jenis pembelajaran yang mamanfaatkan teknologi dalam proses belajar mengajar. Pemanfaatan teknologi informasi pada dunia pendidikan telah diteliti secara luas dan dikenal dengan sebutan "e-learning" dan "virtual university". Penelitian yang telah banyak dilakukan menitikberatkan pada efektivitas pembelajaran berbasis IT yang dibandingkan dengan pembelajaran konvensional (Ramage, 2002) atau bahkan kemungkinan tergantikannya pem-belajaran konvensional dengan pembe-lajaran berbasis IT di perguruan tinggi (Haghirian dan Simon, 2002). Dapat dika-takan bahwa perkembangan teknologi untuk saat ini telah memperoleh banyak pengakuan dan minat dari berbagai kalangan sebagai alternatif atau pengganti proses belajar mengajar melalui tatap muka di kelas (Martin \& Noonan, 2010).

Seperti yang diutarakan oleh Herther (1997) bahwa pembelajaran yang dilaku-kan secara konvensional meskipun menggunakan media pembelajaran melalui tatap muka di kelas telah menjadi hal yang sangat biasa, sehingga penggunaan media pembelajaran dengan teknologi yang baru/canggih menjadi lebih diminati. Pemanfaatan teknologi informasi telah diterapkan secara luas untuk meye-lesaikan permasalahan jarak dalam memperoleh kesempatan menempuh pendidikan formal dan informal. Banyak universitas di negara maju yang meman-faatkan teknologi virtual classroom untuk menyelenggarakan pembelajaran jarak jauh baik secara partial maupun secara simultan dalam satu program. Hal ini menjadi kebutuhan khusus untuk menerapkan pembelajaran berbasis pengalaman dimana universitas dengan instansi yang menyediakan fasilitas preservice memiliki jarak yang cukup signifikan (Chilton, 2012). Di Indonesia, pemebelajaran jarak jauh dengan metode blended learning telah diterapkan oleh Universitas Terbuka. Pembelajaran semacam ini diselenggarakan untuk menyelesaikan masalah jarak dan keterbatasan waktu yang dihadapi oleh peserta didik.

Pembelajaran berbasis game merupakan metode belajar yang kini sedang diminati oleh pelajar. Tidak bisa dipungkiri sesuatu yang diminati sudah tentu menjadi hal yang motivasi. Secara definitive gamifikasi merupakan elemen desain permainan dalam konteks yang memotivasi pengguna(Lichtenwalter \& Baker, 2014; Risqi \& Saputra, n.d.; Rodrigues, Oliveira, \& Rodrigues, 2019; Zainuddin, Shujahat, Haruna, \& Chu, 2020).Konteks pembelajaran berbasis game adalah menggunakan game sebagai media interaktif atau sarana transfer ilmu melalui perantara game. Permainan yang dapat digunakan dalam meningkatkan literasi keuangan adalah permainan dibidang perdagangan, konsumsi dan investasi yang melibatkan pengguna untuk dapat pengalaman virtual berekonomi. Pada penelitian ini, Dosen pengajar dengan metode game based learning menggunakan aplikasi berbasis android dengan nama "Ecrowdwar" yang memanfaatkan studi kasus aktivitas ekonomi yang ada di beberapa wilayah di Kota Malang.

\section{METODE}

Penelitian ini dilaksanakan berdasarkan pengamatan peneliti terhadap pola pengajaran Dosen dimasa pembatasan social berskala besar dimana mahasiswa diminta untuk belajar dirumah. Karena peneliti tidak menentukan atau mengintervensi Dosen dalam metode mengajar dan peneliti hanya menyebarkan tes literasi keuangan, maka penelitian ini lebih mengarah pada penelitian studi komparatif yang membandingkan literasi keuangan pada topik produksi, konsumsi, dan investasi di kelompok A yang diajar dengan belajar berbasis penugasan dan pertemuaan online dan kelompok $B$ dengan metode metode belajar berbasis Game Based Learning selama 8 kali pertemuan. Metode pengumpulan data dilakukan dengan memberikan tes tentang literasi keuangan pada responden, yang kemudian skor tersebut diambil rata-ratanya persubpembahasan literasi keuangan untuk mengetahui perbandingan keterampilan mahasiswa. Sampel penelitian ini adalah mahasiswa di Universitas Negeri Malang dengan metode purposive sampling dengan kondisi kelas yang merepresentasikan program studinya. Responden terbagi 
masing-masing 46 mahasiswa pada kelas pembelajaran online dan 46 mahasiswa pada kelas pembelajaran berbasis game. Karena 2 variabel pengamatan cukup berbeda, maka data terkumpul kemudian di analisis dengan menggunakan metode analisis indepen-dent t-test untuk mengetahui adakah perbedaan rata-ratanya.

\section{HASIL DAN PEMBAHASAN}

Dalam tes literasi yang dilakukan, peneliti menyebarkan 100 soal yang mencakup literasi konsumsi (30 soal), literasi Produksi (33 soal), literasi Investasi (34 soal), dengan hasil pengamatan sebagai berikut,
Tahapan analisis penelitian ini perlu melalui tahapan uji, pertama, dengan jabaran deskriptif hasil uji dari subyek pengematan. Kedua, uji asumsi klasik. Ketiga, menganalisis perbedaan mean dari masing-masing variable dengan uji independent $t$ test, dan perumusan atau analisis hasil penelitian yang dijabarkan sebagai berikut, Klasifikasi Subyek Berdasarkan variable.

Penelitian ini fokus pada 2 variabel game based learning dan online learning (penugasan dan pertemuan online) pembentuk literasi keuangan dengan jabaran sebagai berikut,

Tabel 1 Subvariabel Literasi Keuangan

\begin{tabular}{lcccc}
\hline \multicolumn{1}{c}{ Kelompok Sampel } & N & Mean & $\begin{array}{c}\text { Skor } \\
\text { tertinggi }\end{array}$ & $\begin{array}{c}\text { Skor } \\
\text { terendah }\end{array}$ \\
\hline Online Learning (Literasi Konsumsi) & 46 & 17,26 & 31 & 10 \\
Game Based Learning (Literasi Konsumsi) & 46 & 27,67 & 33 & 13 \\
Online Learning (Literasi Produksi) & 46 & 20,37 & 33 & 8 \\
Game Based Learning (Literasi Produksi) & 46 & 21,78 & 33 & 10 \\
Online Learning (Literasi Investasi) & 46 & 26,11 & 34 & 13 \\
Game Based Learning (Literasi Investasi) & 46 & 14,11 & 27 & 6 \\
\hline
\end{tabular}

Sumber : Peneliti

Hasil pengamatan deskriptif subvariabel literasi keuangan yang meliputi literasi tentang konsumsi, produksi dan investasi menunjukkan adanya perbedaan rata-rata hasil tes yang berbeda dimana metode belajar game based learning memiliki ratarata yang lebih tinggi pada subvariabel literasi konsumsi dan produksi, dan metode belajar online learning memiliki rata-rata yang lebih tinggi pada literasi tentang investasi.

Tabel 2 Distribusi Frekuensi Literasi Keuangan kumulatif

\begin{tabular}{lcccc}
\hline Pembelajaran & Frekuensi & $\%$ & $\begin{array}{c}\text { Mean } \\
\text { Score }\end{array}$ & Std. Dev \\
& & & \\
\hline Game Based Learning & 46 Orang & 50 & 64,021 & 2,083 \\
Online Learning & 46 Orang & 50 & 63,78 & 2,182 \\
\hline
\end{tabular}

Sumber: Peneliti

Tabel di atas menjelaskan bahwa, metode sampling menghasilkan porsi yang sama antara pelajar yang mendapat pembelajaran game based learning maupun online learning. Merujuk pada rata-rata skor menunjukkan ada perbedaan antara metode pembelajaran game based learning dengan metode pembelajaran online learning. Untuk membuktikan perbedaan tersebut berarti secara signifikan, peneliti perlu menggunakan uji independent sample t test.

\section{Uji Asumsi Klasik}

Tahap awal penelitian ini adalah menguji apakah data yang terkumpul memiliki syarat kelayakan untuk dianalisis. Peneliti menggunakan uji asumsi klasik normalitas dan uji homogenitas, dengan hasil sebagai berikut,

Uji normalitas penelitian ini dapat diinterpretasikan pada table normalitas pendekatan Kolmo-gorov-smirnov yang dijabarkan sebagai berikut, 
Tabel 3 Uji Normalitas

\begin{tabular}{|c|c|c|c|c|c|c|c|}
\hline & & & $s$ of N & mality & & & \\
\hline & & & rov-Sm & & & piro-Wil & \\
\hline & Kelompok & Statisitic & df & Sig. & Statistic & df & Sig. \\
\hline Score & Online Learning & .115 & 46 & .162 & .969 & 46 & .249 \\
\hline & GameBLearning & .120 & 46 & .096 & .958 & 46 & .100 \\
\hline
\end{tabular}

a. Lillieforos Significance Correction

\section{Sumber : Olah data Peneliti}

Kolom Kolmogorov-Smirnov menjelas-kan bahwa metode pembelajaran online learning dan game based learning secara signifikan memiliki distribusi literasi keuangan yang normal. Dengan nilai signifikansi atau probabilitas $0.162>0.05$ pada kelompok online learning dan $0.096>0.05$. begitu pula pengujian normalitas data dengan shapiroWilk yang menunjukkan normalitas hasil literasi keuangan dengan signifikansi $0.249>0.05$ pada online learning dan $0.100>0.05$ pada game based learning, dengan demikian dapat disimpulkan bahwa data berdistribusi normal.

Uji Homogenitas digunakan untuk sifat homogen dari data sebelum dianalisis lebih lanjut,
Tabel 4 Uji Homogenitas

Test of Homogeneity of Variance

\begin{tabular}{|c|c|c|c|c|c|}
\hline & & $\begin{array}{l}\text { Levene } \\
\text { Statistic }\end{array}$ & df1 & $\mathrm{df} 2$ & Sig. \\
\hline \multirow[t]{4}{*}{ Score } & Based on Mean & .408 & 1 & 90 & .525 \\
\hline & Based on Median & .349 & 1 & 90 & .556 \\
\hline & $\begin{array}{l}\text { Based on Median and } \\
\text { with adjusted df }\end{array}$ & .349 & 1 & 89.898 & .556 \\
\hline & Based on trimmed mean & .414 & 1 & 90 & .522 \\
\hline
\end{tabular}

Sumber : Peneliti

Table 4 Levene Statistic diperoleh nilai 0.408 dengan signifikansi dengan dasar pengukuran median data sebesar $0.525>$ 0.05. maka dapat dikatakan bahwa data dari populasi memiliki varian yang sama, atau sampel pelajar yang memperoleh metode pembelajaran online learning dan game based learning mempunyai varian literasi keuangan yang sama.

\section{Uji Independent t Test}

Tujuan utama dari uji independent $t$ test adalah mengetahui apakah ada beda ratarata literasi keuangan pelajar yang mendapat pengajaran metode online learning dan game based learning. Data menunjukkan bahwa,

Tabel 5 Uji Independent t test

\begin{tabular}{llrr}
\hline & & \multicolumn{2}{c}{$\begin{array}{c}\text { Score } \\
\text { Equal Variances not } \\
\text { Assumed }\end{array}$} \\
\hline Levene's Test for & F & $\begin{array}{c}\text { Equal variances } \\
\text { assumed }\end{array}$ & $\begin{array}{c}\text { Equmed } \\
\text { Equality of Variance }\end{array}$ \\
& Sig. & 0.408 & - \\
& T & 0.525 & 0.079 \\
T-test for Equality of & Df & 0.079 & 89,81 \\
Means & Sig. (2-tailed) & 90 & 0.937 \\
& Mean difference & 0.937 & 0.239 \\
95\% Confidence Internal & Std. Error Difference & 0.239 & 3.01709 \\
of the Difference & Lower & 3.01709 & -5.754 \\
\hline
\end{tabular}

\section{Sumber : Peneliti}

Levene's test for equality of variances memiliki $F$ hitung skor literasi keuangan sebesar 0.408 (equal variance assumed) dengan signifikansi sebesar $0.525(p>0.05)$. Karena probabilitas $>0.05$, maka hipotesis nol $\left(\mathrm{H}_{0}\right)$ yang menyatakan skor literasi keuangan kedua model pembelajaran adalah identik, diterima, atau skor literasi keuangan pelajar sama walaupun memiliki rata-rata hasil yang berbeda pada subvariabel (table 1). Kondisi ini disinyalir karena metode pembelajaran game based learning menggunakan permainan yang berfokus kepada studi kasus yang berhubungan dengan keterampilan konsumsi dan produksi tapi lemah pada pemantapan konsep investasi, begitu pula sebaliknya, pada metode pembelajaran online learning yang lebih menitik beratkan 
pematangan konsep literasi keuangan secara teoritis terutama pada literasi investasi. Sehingga kedua metode pembelajaran sama-sama memiliki kelebihan pada beberapa aspek literasi keuangan.

Karena tidak ada perbedaan yang nyata dari kedua varians, maka perlu dilakukan analisis lanjutan dengan equality of means test dengan menggunakan uji $\mathrm{t}$ berdasar pada kolom equal variance assumed.

Uji t berdasar pada equal variance assumed menunjukkan nilai t sebesar 0.079 dengan signifikansi $0.937>0.05$ (1-tailed) atau uji $\mathrm{t}$ dua sisi menjelaskan bahwa nilai $\mathrm{t}$ sebesar $(0.937 / 2)=0.4685>0.025$. hasil analisis uji tmenyimpulkan bahwa skor literasi keuangan pelajar, ditinjau dari pembelajaran menggunakan metode online learning dan game based learning pada dasarnya tidak ada perbedaan.

\section{SIMPULAN DAN SARAN}

Hasil penelitian merupakan evaluasi pembelajaran dimasa pandemic COVID-19 di Kota Malang. Dari penelitian ini dapat disimpulkan bahwa Keahlian-keahlian mendasar ditengah pembelajaran yang mendadak online masih dirasa kurang memberikan dampak pada perkembangan literasi keuangan pelajar. Hal ini dapat dilihat dari hasil analisis metode pembelajaran penugasan, pertemuan (online learning) dan metode belajar game based learning, walaupun hasil finansial literasi dalam aspek konsumsi, produksi dan investasi cukup menunjukkan perbedaan skor, tapi skor kumulatif literasi keuangan secara signifikan tidak cukup berdampak untuk meningkatkan literasi keuangan mahasiswa. Dengan kata lain tidak ada perbedaan antara online learning dan game based learning sesuai hasil analisis. Kondisi yang benar-benar mendadak dan kurang persiapan membuat luaran dari pembelajaran ekonomi terasa kurang optimal meningkatkan literasi pelajar terhadap ekonomi. Penanaman, pengembangan dan eksplorasi diri untuk meningkatkan pemahaman kita terhadap perekonomian pribadi, mikro maupun makro merupakan hal yang sangat urgent. Literasi keuangan merupakan pertahanan terakhir dimasa kondisi ekonomi yang memburuk, keterbatasan lapangan pekerjaan ,kebijakan keuangan super ketat. Perlu kiranya kita sebagai pendidik untuk menggunakan metode lain dalam pengajaran, terutama pada metode-metode pembelajaran yang tidak diamati dalam penelitian ini.

\section{UCAPAN TERIMAKASIH}

Apresiasi luar biasa terhadap rekanrekan pengajar yang terus mengembangkan diri, mempersiapkan diri demi memberikan yang terbaik kepada peserta didik dimasa pandemic COVID-19. Terima kasih peneliti ucapkan pada rekan-rekan responden, peserta didik, Institusi dan redaktur jurnal yang sangat membantu dan menyempurnakan artikel ini. Semoga negeri ini segera pulih

\section{DAFTAR PUSTAKA}

Akmal, H., \& Saputra, Y. E. K. A. (2016). Analisis tingkat literasi keuangan. Jebi (Jurnal Ekonomi Dan Bisnis Islam), 1(2), 235-244.

Chang, C. C., Liang, C., Chou, P. N., \& Lin, G. Y. (2017). Is game-based learning better in flow experience and various types of cognitive load than non-gamebased learning? Perspective from multimedia and media richness. Computers in Human Behavior, 71, 218-227.

https://doi.org/10.1016/j.chb.2017.01.0 31

Jagušt, T., Botički, I., \& So, H. J. (2018). Examining competitive, collaborative and adaptive gamification in young learners' math learning. Computers and Education, 125(June), 444-457. https://doi.org/10.1016/j.compedu.2018 .06 .022

Kerr, G. (2016). Financial Literacy Outcome Indicators. Prosper Canada

Li, Q., Guan, X., Wu, P., Wang, X., Zhou, L., Tong, Y., ... Feng, Z. (2020). Early transmission dynamics in Wuhan, China, of novel coronavirus-infected pneumonia. New England Journal of Medicine, 382(13), 1199-1207. https://doi.org/10.1056/NEJMoa200131 6

Lichtenwalter, S., \& Baker, P. (2014). 
Teaching About Oppression Through Jenga: A Game- Based Learning Example For Social. Journal of Social Work Education Teaching (December), 37-41.

https://doi.org/10.5175/JSWE.2010.20 0800080

Martin, F., \& Noonan, D. (2010). Synchronous technologies for online teaching. 2010 International Conference on Technology for Education, T4E 2010, 1-4. https://doi.org/10.1109/T4E.2010.5550 062

Murniatiningsih, E. (2017). Pengaruh Literasi Ekonomi Siswa, Hasil Belajar Ekonomi, Dan Teman Sebaya Terhadap Perilaku Konsumsi Siswa SMP Negeri di Surabaya Barat. Jurnal Ekonomi Pendidikan Dan Kewirausahaan, 5(1), 127-156. https://doi.org/p-ISSN 2303324X, e-ISSN 2579-387X

Nurfitriyani, A. (2019). Ini Sektor yang Jadi Penopang Utama Pertumbuhan Ekonomi Indonesia.

Ramaci, T., Barattucci, M., \& Ledda, C. (2020). Social Stigma during COVID-19 and its Impact on HCWs Outcomes, 113.

Ramage, T. R. (2002). Parkland College The "No Significant Difference" Phenomenon: A Literature Review The "No Significant Difference" Phenomenon: A Literature Review. Dr. Thomas R. Ramage Scholarship, Paper 1.

Risqi, M., \& Saputra, U. (n.d.). LexiPal: Design , Implementation and Evaluation of Gamification on Learning Application for Dyslexia, 131(7), 37-43.

Rodrigues, L. F., Oliveira, A., \& Rodrigues, H. (2019). Main gamification concepts: A systematic mapping study. Heliyon, $5(7)$, e01993. https://doi.org/10.1016/j.heliyon.2019.e 01993

Satrio, Y. D. (2012). Analisis financial literacy mahasiswa Fakultas Ekonomi Universitas Negeri Malang. (Doctoral dissertation, Tesis, Program Pasca Sarjana Prodi S2 Pendidikan Ekonomi Fakultas Ekonomi Universitas Negeri Malang). Universitas Negeri Malang.

Wardoyo, C., Dwi Satrio, Y., \& Ma'ruf, D.
(2020). Effectiveness of Game-Based Learning - Learning in Modern Education. KnE Social Sciences, 2020(2001), 81-87. https://doi.org/10.18502/kss.v4i7.6844

Zainuddin, Z., Shujahat, M., Haruna, H., \& Chu, S. K. W. (2020). The role of gamified e-quizzes on student learning and engagement: An interactive gamification solution for a formative assessment system. Computers and Education, 145, 103729. https://doi.org/10.1016/j.compedu.2019 .103729

Zhang, Y., \& Ma, Z. F. (2020). Impact of the COVID-19 pandemic on mental health and quality of life among local residents in Liaoning Province, China: A crosssectional study. International Journal of Environmental Research and Public Health, 17(7). https://doi.org/10.3390/ijerph17072381 